\title{
Auditing financial statements in insurance enterprises: The case of Vietnam
}

\author{
Thi Mai Anh Nguyen a and Thi Tam Le ${ }^{b^{*}}$
}

${ }^{a}$ Hanoi University of Natural Resources and Environment, Vietnam

${ }^{b}$ Thuyloi University, 175 Tay Son, Dong Da, Ha Noi, Vietnam

\section{H R O N I C L E}

Article history:

Received: October 2, 2018

Received in revised format: No-

vember 15,2018

Accepted: November 22, 2018

Available online:

November 22, 2018

Keywords:

Audit quality of financial state-

ments

Audit procedures

Audit techniques

Insurance enterprises

Risk - based approaches

\section{A B S T R A C T}

\begin{abstract}
This study is conducted to study the implementation of the audit techniques and procedures executed by auditors using risk-based approach. The study also determines factors affecting audit quality of financial statements in Vietnamese insurance enterprises. Quantitative method is used in the study where questionnaires are sent to 250 independent auditors and 186 valid questionnaires are encrypted, declared and entered into SPSS software version 22.0. The results show that in audit techniques, except for document testing and verification technique, there were significant differences in application level of material testing, observation, interview, calculation and analysis techniques between big 4 firms and non-big 4 firms. The analysis also confirms that the most significant difference was between the two audit groups. In audit procedures, while control testing is not performed singly, detailed testing can be performed alone at all three assurance levels and the analysis is performed alone in the assurance level of 1 . It is possible to combine them in these procedures with the assurance level of 2 and 3 . On the other hand, the combination of these three procedures is only guaranteed at level 3 . The results of the factor analysis and regression model test demonstrate that there were six factors influencing the audit quality of financial statements in insurance enterprises; namely audit method, auditors' quality, awareness of auditors and director board, characteristics of insurance enterprises, legal environment and position of the audit firm. In particular, audit method and auditors' quality are the strongest factors.
\end{abstract}

C) 2019 by the authors; licensee Growing Science, Canada

\section{Introduction}

One of the primary objectives of any business units is devoted to reach higher profitability, however, insurance enterprises have many characteristics different from the normal business activities. Their products are risks which are invisible and unexpected. There is a reverse accounting cycle that the insurance companies collect premium first and pays compensations after the insured events. Their idle capital is usually invested in financial activities, business processes appear complicated legal relationships and their operation scale is broad and geographically dispersed. The characteristics of insurance enterprises determine the content and techniques and procedures for auditing financial statements. However, there are a few studies in the world and more specifically in Vietnam focusing on auditing financial statements in insurance enterprises. On the other hand, due to the stringent requirements of

* Corresponding author. Tel. +84-984537282

E-mail address: lethitam@tlu.edu.vn (T. T. Le) 
the integration and the increasing demand on auditing, Vietnamese audit firms are facing significant amount of pressures on the workload and time of audit completion. It also requires further efforts to improve the audit quality in general and the audit quality of financial statements in insurance enterprises in particular.

The study is conducted to deal with two main objectives. The first objective is to examine the application level of audit techniques and procedures in financial statements by risk-based approaches in Vietnamese insurance enterprises. The second objective is to detect the factors affecting audit quality of financial statements in Vietnamese insurance enterprises.

\section{Research overview}

Since the financial crisis together with the scandal of many major corporations around the world, auditing and accounting professional associations have recognized and made changes in auditing sector. One of those changes is the conversion of traditional approaches to risk-based approach. The risk-based approach was adopted by a number of large audit firms in the late 1990s. Bell et al. (1997) was the first to try to perform an investigation through practical understanding of the audit process in KPMG. According to Bell et al. (1997), instead of performing a traditional approach based on examining operations and balances on the financial statements, auditors explored the business strategy of the client, predicted the risks and their responses to the risks, and determined the effects of risks on material misstatement in the financial statements. As a result, auditors can design the audit procedures to handle the identified risks. Salterio and Weirich (2002) examine the differences between traditional audit approach and risk-based approach. The approach requires auditors to have wise understanding of customers, expertise and analysis skills. Griffiths (2005) states that risk-based audit approach does not come from control procedures, but it based on the objectives of the organization and the risks that affect the objectives. The approach help to evaluate control activities to manage those risks. Knechel (2007) also supports that through comprehensive understanding of the customer's business environment, auditors identify the risks leading to material misstatement in the financial statements. Then it allocates human resources to focus on higher risk areas and help auditing activities more effectively. Besides, Adam (2012) analyzes the necessary requirements to identify business risk factors into the audit model and suggests a model, which has three steps: business risk assessment, audit evidence collection, and feedback loop. Prinsloo (2008) sums up previous studies on audit approaches and concludes that the risk based audit approach is an indispensable trend in the audit development process to provide reasonable assurance to the audited entity, comply with all professional rules, and narrow the audit expectation gap. Mentz (2014) builds the quantitative model of audit procedures to address the risk of material misstatement by three assurance levels which can be seen in Table 1.

\section{Table 1}

Combined model of audit testing and the assurance level

\begin{tabular}{|c|c|c|c|c|c|c|c|c|c|c|c|c|c|c|}
\hline \multirow[b]{3}{*}{ Control testing } & \multicolumn{8}{|c|}{ The assurance level of 3 (high) } & \multicolumn{4}{|c|}{$\begin{array}{l}\text { The assurance level of } 2 \text { (me- } \\
\text { dium) }\end{array}$} & \multirow{2}{*}{\multicolumn{2}{|c|}{$\begin{array}{c}\text { The assurance level } \\
\text { of } 1 \text { (low) } \\
\text { Performing substan- } \\
\text { tive analytical proce- } \\
\text { dures alone }\end{array}$}} \\
\hline & \multicolumn{5}{|c|}{$\begin{array}{l}\text { Combination of substan- } \\
\text { tive analytical procedures } \\
\text { and control testing }\end{array}$} & \multicolumn{3}{|c|}{$\begin{array}{l}\text { Performing } \\
\text { substantive an- } \\
\text { alytical proce- } \\
\text { dures alone }\end{array}$} & $\begin{array}{l}\text { Combination } \\
\text { of substantive } \\
\text { analytical pro- } \\
\text { cedures and } \\
\text { control testing }\end{array}$ & \multicolumn{3}{|c|}{$\begin{array}{l}\text { Performing } \\
\text { substantive } \\
\text { analytical } \\
\text { procedures } \\
\text { alone }\end{array}$} & & \\
\hline & 2 & 2 & 1 & 1 & 1 & 0 & 0 & 0 & 1 & 0 & 0 & 0 & 0 & 0 \\
\hline Analysis procedue & 1 & 0 & 2 & 1 & 0 & 2 & 1 & 0 & 0 & 2 & 1 & 0 & 1 & 0 \\
\hline Detail testing & 0 & 1 & 0 & 1 & 2 & 1 & 2 & 3 & 0 & 0 & 1 & 2 & 0 & 1 \\
\hline Total assurance level & 3 & 3 & 3 & 3 & 3 & 3 & 3 & 3 & 2 & 2 & 2 & 2 & 1 & 1 \\
\hline$\%$ assurance level & \multicolumn{8}{|c|}{$95 \%$} & \multicolumn{4}{|c|}{$86 \%$} & \multicolumn{2}{|c|}{$63 \%$} \\
\hline$\%$ audit risk & \multicolumn{8}{|c|}{$5 \%$} & \multicolumn{4}{|c|}{$14 \%$} & \multicolumn{2}{|c|}{$37 \%$} \\
\hline
\end{tabular}

If transactions, account balance or disclosure are critical and make risks of material misstatement at database, the assurance level will be the highest by 3 . If transactions, account balance or disclosure are critical but are not likely to make risks of material misstatement at the database, the level of assurance is 
on average and equal to 2 . If account balance or disclosure not important and is not likely to make risks of material misstatement at the database, the level of assurance is by 1 . In addition, changing in auditing approach will make the changes about scale, scope of audit techniques and procedures (Dinh, 2016). According to Bell et al. (1997), business risk identification is the basis to design audit procedures by increasing substantive analytical procedures for irregular operations and only performing tests of controls for regular operations. Cullinan and Sutton (2002) also note that in the risk - based approach, analysis technique is strengthened and promoted throughout the audit process.

In Vietnam, the risk-based approach has gained more attention since Ministry of Finance issued new audit standards in 2014. As a new approach, there are a few authors in Vietnam studying the audit of financial statements by risk-based approach. On the other hand, many audit firms in Vietnam have not applied the approach for all customers. Typically, this approach receives popularly in listed enterprises and insurance enterprises do not use this method more frequently. Therefore, the first research objective is to examine auditors to perform audit techniques and procedures in auditing financial statements of the insurance enterprises by risk-based approach.

Along with the development of auditing sector in general, auditing activities in Vietnam were also developed. Clients and audiences using the auditing results are more aware of the role and effect of the audits in the market economy. As a result, it is necessary for audit firms to improve audit quality and enhance their image. Accordingly, the research on audit quality has become a topic which has received much attention in Vietnam. However, only some researches have examined the factors affecting the audit quality through quantitative research. Moreover, there is no study relating to audit financial statements in Vietnamese insurance enterprises. Therefore, besides the audit techniques and procedures, this study also considers the factors affecting the audit quality of financial statements in insurance enterprises. In the auditing field, the audit quality of financial statements consists of professional quality and service quality (Duff, 2004). Professional quality emphasizes that auditors comply with standards during auditing process and detect and report material misstatements on financial statements (Aldihizer et al., 1995; Krishnan \& Schauer, 2000; DeAngelo, 1981; Palmrose, 1988). In terms of a service perspective, the audit quality of the financial statement expresses the satisfaction level of users about objectivity and reliability in audit opinions, about content and format of auditors' reports (FRC, 2008, Duff, 2004; Boon et al., 2007). The items of the audit quality in financial statements are developed from the previous researches such as (1) Content and format of auditors' reports are clear and understandable; (2) Audit opinions are objective and reliable (3) Audited financial statements do not have any misleading materials; (4) Insurance enterprises are satisfied with the audit services.

Independent auditing and insurance businesses are the sectors that have a great influence on the socioeconomic situation of a country. Therefore, these two sectors are strongly controlled by the legal system and inspection activities of state agencies. Moreover, many studies such as Martar (2012); Phan (2015), Defond and Zhang (2014), Do and Trung (2016), Bui (2014) also show that the legal environment has a strong impact on both auditors' ethical behavior and audit quality. The first hypothesis is developed:

H1: The legal environment has a positive relationship with the audit quality of financial statements in Vietnamese insurance enterprises.

The business position is considered as an invaluable asset which represents the competitive strength and plays an extremely important role for the success of an enterprise. In the auditing field, the position of audit firms is reflected in the scale, reputation and audit fees. The previous researches confirm that the scale, reputation and prestige of audit firms affect the audit quality (Defond \& Zhang, 2014; Kenchel, 2007; DeAngelo, 1981). Besides due to the typical characteristics of the sector, insurance enterprises are often audited by large-size and reputable auditing firms. The second hypothesis is suggested:

H2: The position of audit firms has a positive relationship with the audit quality of financial statements in Vietnamese insurance enterprises.

Auditing is a highly specialized and influential profession that requires auditors to comply professional 
standards. The finding is supported by Carcello et al. (1992) and Boon et al. (2007) that awareness and attitude of auditors and director board including independence, cautious attitude and professional skepticism have a strong influence on the audit quality of financial statements. Insurance enterprises are public interest entities and many stakeholders are interested in auditing results. Therefore, auditors raise the compliance with the professional standards and the board of directors pay special attention to quality control and improve the service quality when auditing financial statements of customers. This leads to the development for the third hypothesis:

H3: The awareness of auditors and director board has a positive relationship with the audit quality of financial statements in Vietnamese insurance enterprises.

Previous studies have also found that the quality of human resources has a great impact on the audit quality. Richard and Jason (2006) state that auditors' quality is to represent the capacity and experience in the audits. Tuukka (2012) and Moroney (2007) comment that experienced auditors will perform audit procedures, collect and process audit evidences more efficiently than less experienced auditors. Moreover, auditors who have deep knowledge of customers' expertise field will increase their abilities to detect risks (Sarwoko \& Sukrisno, 2014; Granberg \& Hoglund, 2011; Low, 2004). According to Boon et al. (2007), auditors with professional qualification and experience will make customers satisfy with audit results. With fastidious customers such as insurance enterprises, the quality of auditors becomes increasingly important that requires not only auditors with professional qualification but also extensive experience and knowledge of insurance sector. Therefore, we proposed the fourth hypothesis as follows:

H4: The auditors' quality has a positive relationship with the audit quality of financial statements in Vietnamese insurance enterprises.

According to ISA 300, a pre-designed audit program will help auditors arrange and organize working steps more logically. Audit techniques and procedures are considered the factors significantly impacting on time, cost and effectiveness of audits (Dinh, 2016). In addition, in the era of information technology, auditors must have much knowledge of technology to design audit procedures in insurance enterprises with high demand for computing. Therefore the finding shows that audit method influences on the audit quality of the financial statements. This leads to the fifth hypothesis:

H5: Audit method has a positive relationship with the audit quality of financial statements in Vietnamese insurance enterprises.

Customer characteristics are also factors that affect decision making, audit procedures and audit quality. In particular, the items including management characteristics, business characteristics, accounting characteristics, characteristics of internal control are mostly mentioned in the existing literature. According to Messier et al. (2014), Tuukka (2012), Krishnan et al. (2000), the integrity and management capacity of director board significantly influence on the risk assessments, the design of audit procedures and the number of audit evidence collected. When there are more complicated business lines, there is a bigger potential of errors in business activities and there is a more potential of frauds on financial statements. As a results, auditors must design and use more audit techniques. This is supported by Malaescu \& Sutton (2013); Munro \& Stewart (2009) that auditors will reduce the substantive analytical procedures and increase tests of controls if they believe in internal control system of customers. This leads to the development of the sixth hypothesis:

H6: The characteristics of insurance enterprises have positive relationships with the audit quality of financial statements in Vietnamese insurance enterprises.

\section{Research methodology}

Business activities of insurance enterprises are quite typical, their products are risky business. These characteristics require audit firms auditing financial statements in the insurance enterprises to be large and highly reputable. Although the number of audit firms in Vietnam is about 150, only 10 audit firms 
are eligible to audit financial statements at insurance enterprises. There are 4 big four firms and 6 non big four firms. The study is conducted to deal with two objectives. The first objective is to examine the differences in the techniques and procedures of auditing financial statements in Vietnam insurance enterprises between two groups of audit firms. The second is to investigate the factors influencing the audit quality of financial statements in Vietnam insurance enterprises. In order to achieve the above objectives, the quantitative method through survey questionnaire was adopted. The questionnaire is divided into three sections. The first section requests the respondents to complete demographic profile. The objective of this section is intended to gather information related to the background of the respondents such as gender, experience years, positon and educational background. The second section includes 14 questions related to techniques and procedures for auditing financial statements of insurance enterprises. Of which, 7 questions represent audit techniques recognized in the ISA 500 (material testing, document testing, observation, calculation, interview and analysis technique), 7 remaining questions indicate audit procedures which are inherited by the study of Mentz (2014). The final section deals with the factors impacting on the audit quality of financial statements. Therefore, the questions are designed using five-point Likert scale from 1 as "totally disagreeable" to 5 as "totally agreeable". The items of independent variables and dependent variables are developed from the previous studies which can be seen in Table 2.

\section{Table 2}

The items of independent variables and dependent variable

\begin{tabular}{|c|c|c|}
\hline Sources & Independent variables & Code \\
\hline \multirow{4}{*}{$\begin{array}{l}\text { Phan (2015), } \\
\text { Bui (2014) }\end{array}$} & 1. Legal environment & $\mathbf{L E}$ \\
\hline & $\begin{array}{l}\text { 1.1. The legal provisions on auditing and accounting in insurance sector are complete and compre- } \\
\text { hensive }\end{array}$ & LE1 \\
\hline & 1.2. Frequency of inspection and control by the authorities & LE2 \\
\hline & 1.3. Measures and punishments for violations & LE3 \\
\hline \multirow{4}{*}{$\begin{array}{c}\text { Defond \& Zhang (2014), } \\
\text { Kenchel (2007), } \\
\text { DeANGELO (1981) }\end{array}$} & 2.The position of audit firms & PF \\
\hline & 2.1. The reputation of audit firms & PF4 \\
\hline & 2.2. The sale of audit firms & PF5 \\
\hline & 2.3. Cost of audit firms & PF6 \\
\hline \multirow{4}{*}{$\begin{array}{c}\text { Carcello et al. (1992), Boon et } \\
\text { al. (2007) } \\
\text { Duff (2004) }\end{array}$} & 3. Awareness of auditors and director board & $\overline{\mathbf{A A}}$ \\
\hline & 3.1. Awareness of compliance with professional standards & AA7 \\
\hline & 3.2. Awareness of improvement the control activities of audit quality & AA8 \\
\hline & 3.3. Awareness of improvement quality of audit services & AA9 \\
\hline \multirow{3}{*}{$\begin{array}{l}\text { Richard \& Jason (2006) } \\
\text { Tuukka (2012), Moroney } \\
\text { (2007) }\end{array}$} & 4. Auditors' quality & AQ \\
\hline & 4.1. Ability of auditors & AQ10 \\
\hline & 4.2. Experience of auditors & AQ11 \\
\hline Sarwoko \& Sukrisno (2014) & 4.3. Knowledge of auditors in insurance sector & AQ12 \\
\hline \multirow{5}{*}{$\begin{array}{l}\text { Phan (2015); Bui (2014); } \\
\quad \text { PCAOB (2014) }\end{array}$} & 5. Audit method & $\mathbf{A M}$ \\
\hline & 5.1. The audit program of financial statements is designed appropriately & AM13 \\
\hline & 5.2. Audit techniques are applied flexibly & AM14 \\
\hline & 5.3. Audit procedures are implemented fully & AM15 \\
\hline & 5.4. There has the support of information technology in auditing financial statements & AM16 \\
\hline & 6. Characteristics of insurance enterprises & CI \\
\hline \multirow{2}{*}{$\begin{array}{c}\text { Messier et al. (2014), Tuukka } \\
\text { (2012) }\end{array}$} & 6.1. Integrity of director board & CI17 \\
\hline & 6.2. Management capacity of director board & CI18 \\
\hline \multirow[t]{2}{*}{ Bui (2014) } & 6.3. Complexity in business characteristics & CI19 \\
\hline & 6.4. Complexity in transaction processing & CI 20 \\
\hline \multirow[t]{3}{*}{$\begin{array}{l}\text { Malaescu \& Sutton (2013); } \\
\text { Munro \& Stewart (2009) }\end{array}$} & 6.5. Quality of internal control and internal audit & CI21 \\
\hline & Dependent variable & Code \\
\hline & Audit quality of financial statements & FS \\
\hline \multirow[t]{2}{*}{ FRC (2008) } & Content and format of auditors' reports is clear and understandable & FS1 \\
\hline & Audit opinions is objective and reliable & FS2 \\
\hline \multirow{2}{*}{$\begin{array}{l}\text { DeANGELO (1981) } \\
\text { Duff (2004) }\end{array}$} & Financial statements after audited are no longer material misstatements & FS3 \\
\hline & Insurance enterprises satisfy with the audit service & FS4 \\
\hline
\end{tabular}

According to Hair et al. (2006), in exploratory factor analysis, the ratio between items and factors is by 5. With total 21 items, minimum sample scale is 105 items in this study. By Tabachnick and Fidell (2007), regression analysis achieves the best results when minimum scale is $n=8 p+50$ where $n$ is the minimum scale and $p$ is the number of independent factors in the model. This study has a 6 independent factors so that the minimum size must be 98 observations. To respond the requests and ensure for the 
research results, we select a sample size of 250 respondents. Survey questionnaires are sent to respondents by manual and online from 2015 to 2016. Respondents are auditors working in audit firms who have audited financial statements in insurance enterprises. 186 auditors responded validly including 100 auditors from big four firms and 86 auditors from non-big four firms, making the response rate as 74.4\%. Valid questionnaires were encoded, declared, and entered into SPSS software version 22.0. From this software, the data continues to be processed through the following tools such as descriptive statistics, independent samples T-Test, reliability testing; factor analysis, correlation analysis and regression analysis. Descriptive statistics is performed to calculate the frequency and percentage of background of target respondents and the assurance level of audit procedures as well as mean, mode, min and max values of items. The independent samples T-Test is used to determine whether there is statistically significant different in audit techniques between big four firms and non-big four firms. Then, the analysis tools are performed to examine the factors influencing the audit quality of financial statements in insurance enterprises.

\section{Results and Discussion}

\section{Background of respondents}

Table 3 shows general information of respondents. The number of females surveyed are higher than the number of males. This is also consistent with the professional characteristics of auditing in Vietnam.

Table 3

The characteristics of the sample

\begin{tabular}{|c|c|c|c|}
\hline & Background & Frequency & Percentage (\%) \\
\hline \multirow[t]{2}{*}{ 1. Gender } & Female & 107 & 57,5 \\
\hline & Male & 79 & 42,5 \\
\hline \multirow[t]{3}{*}{ 2. Position } & Junior & 17 & 9,1 \\
\hline & Senior & 103 & 55,4 \\
\hline & Manager & 66 & 35,5 \\
\hline \multirow{3}{*}{$\begin{array}{l}\text { 3. Years of experi- } \\
\text { ence }\end{array}$} & Less than 5 years & 94 & 50,5 \\
\hline & From 5 years to 10 years & 84 & 45,2 \\
\hline & More than 10 years & 8 & 4,3 \\
\hline \multirow[t]{3}{*}{ 4. Education level } & College & 0 & 0 \\
\hline & University & 165 & 88,7 \\
\hline & Post - graduate & 21 & 11,3 \\
\hline
\end{tabular}

About the working position, senior occupies the highest rate (55.4\%), followed by the managers $(35.5 \%)$ and juniors $(9.1 \%)$. In experience years, the number of people working less than 5 years is $50.5 \%$; from 5 to 10 years owning $45.2 \%$ and more than 10 years accounting for $4.3 \%$. University level possesses the highest rate of $88.7 \%$, the post-graduate level of $11.3 \%$, and college level of zero. This is also perfectly suitable to a complex and specific industry such as auditing which requires high professional qualifications.

\section{Auditing Techniques}

Table 4 and Table 5 show the results of audit techniques between Big Four firms and Non Big Four firms. Auditors of two groups perform a combination of techniques including material testing, document testing, observation, interview, analysis, calculation and verification when auditing the financial statements in insurance enterprises (see in Table 4). The exception of documentation and verification techniques, the remaining techniques differ in the level of application between the two groups (see in Table 5). Document testing is the most commonly used when auditing financial statements by two audit groups because this technique has the highest mean value (see in Table 4). This popularity is rooted in the characteristics of document testing technique that is relevant to verify and test the information. Besides, the technique is simple and convenient in the collection of audit evidences. Verification technique: In insurance enterprises, there are many complex legal relationships with insurance buyers and beneficiaries. Therefore, these objects are strictly controlled by functional departments such as department of insurance policy, department of insurance fee, management department and policy monitoring 
department. Accordingly, mistakes are rarely occurred in the existing database. This also explains why this technique is used at the medium level by the two audit groups. Based on Table 4, the mean score of verification technique for non-big four $($ mean $=3,14)$ is higher compared with the mean score of big four firm (mean $=3,10)$. The result of the independent samples $\mathrm{T}-$ Test in Table 5 also indicates no significant difference in verification technique between the two audit groups. In Table 5, there are less significant differences for the application level of material technique, observation technique and calculation technique between the two groups. For the big four firms, the mean score for the three techniques in Table 4 respectively are 2.87, 2.95 and 3.95. Therefore, the application level of these techniques in turn are ranked the seventh, sixth and third. While with non-big four firms, the mean score for the three techniques are 3.11,2.60 and 4.25, respectively and the application level of these techniques in turn are ranked the fourth, seventh and second. The application level of interview technique yields a significant difference between the two groups (see in Table 5). This technique is ranked the fourth in big four firms while it is ranked the sixth in non-big four firms (in Table 4). It is explained that big four firms apply more the interview technique in stage of finding out internal control system in insurance enterprises. In contrast, non-big four firms apply fewer techniques but focus on detailed testing about transactions, balances and explanatory information. Specially, the result of the independent samples $\mathrm{T}-\mathrm{Test}$ in Table 5 shows that the most significant difference in the application level of analysis technique exists between the two groups. The mean score for analysis technique is higher required by the auditors in the big four $(4,16)$ compared with mean score by auditors in the Non Big Four (3.08). This technique is much applied by auditors in the big four firms with ranking the second while it is less applied in the non-big four firm with ranking the fifth.

\section{Table 4}

The application level of audit techniques between the two groups

\begin{tabular}{lcccccr}
\hline \multicolumn{1}{c}{ Auditing technique } & \multicolumn{3}{c}{ Big Four } & \multicolumn{3}{c}{ Non Big Four } \\
\cline { 2 - 7 } & Rank & Mean & Std. Deviation & Rank & Mean & Std. Deviation \\
\hline Material testing & 7 & 2,87 & .518 & 4 & 3,11 &, 605 \\
Document testing & 1 & 4,32 & .730 & 1 & 4,47 & .754 \\
Observation & 6 & 2,95 & .472 & 7 & 2,60 & 811 \\
Interview & 4 & 3,65 & .537 & 6 & 3,02 & .624 \\
Verification & 5 & 3,10 & .495 & 3 & 3,14 & .646 \\
Calculation & 3 & 3,95 & .809 & 2 & 4,25 & .678 \\
Analysis & 2 & 4,16 & .556 & 5 & 3,08 & .546 \\
\hline
\end{tabular}

Table 5

The independent samples $\mathrm{T}$ - Test of audit techniques between two groups

\begin{tabular}{|c|c|c|c|c|c|}
\hline \multirow[t]{2}{*}{ Auditing techniques } & \multirow{2}{*}{$\begin{array}{l}\text { Levene's } \\
\text { Test }\end{array}$} & \multicolumn{2}{|c|}{ t-test for Equality of Means } & \multirow[t]{2}{*}{ Mean Difference } & \multirow[t]{2}{*}{ Results } \\
\hline & & $\begin{array}{l}\text { Equal variances as- } \\
\text { sumed }\end{array}$ & $\begin{array}{l}\text { Equal variances not as- } \\
\text { sumed }\end{array}$ & & \\
\hline Document testing & .418 & .173 & & -.149 & No difference \\
\hline Verification & .002 & & .582 & -.047 & \\
\hline Material testing & .212 & .005 & & -.235 & Difference but less sig- \\
\hline Observation & .000 & & .001 & & nificant \\
\hline Calculation & .984 & .007 & & -.302 & \\
\hline Interview & .167 & .000 & & .626 & Significant difference \\
\hline Analysis & .325 & .000 & & 1.071 & \\
\hline
\end{tabular}

Table 6 shows the results about the application level of audit procedures by auditors. Whether the risk assessment of material misstatement is low or high, auditors do not perform tests of controls alone. It is explained that internal control of insurance enterprises do not guarantee absolutely about the validity to detect, prevent and handle all errors in financial statements. Besides, the implementation of detailed testing alone appears at all three levels. This result is supported by previous study (Mentz, 2014). 19.5\% of auditors reflect that the implementation of the single analysis procedure is at the assurance level of 1. This result is different from Mentz's study (Mentz, 2014). According to Mentz (2014), auditors can perform the single analysis procedure at the assurance level of 2 . The combination of control testing and analytical procedure; of control testing and detailed testing; of analytical procedure and detailed testing are implemented at all three assurance levels. At the level by 1 , auditors perform the combination of control testing and analytical procedures with the highest rate $(34.4 \%)$ while at the level by 2 , 
implementing the combination of analytical procedure and detailed testing is ranked as the highest $(40.9 \%)$. In addition, the combination of analytical procedure and detailed testing is the highest $(23.1 \%)$ at the assurance level of 3 . There are 83 auditors performing the combination of control testing, analytical procedure and detailed testing at the assurance level of 3 (accounting for $44.6 \%$ ) and there is no auditor to perform this procedure at the level of 1 and 2. These results are similar to Mentz (2014).

\section{Table 6}

The assurance level of audit procedures

\begin{tabular}{|c|c|c|c|c|c|c|}
\hline \multirow[b]{2}{*}{ Audit procedures } & \multicolumn{2}{|c|}{ The assurance level by 1} & \multicolumn{2}{|c|}{ The assurance level by 2} & \multicolumn{2}{|c|}{ The assurance level by 3} \\
\hline & Quantity & $\begin{array}{l}\text { Percentage } \\
(\%)\end{array}$ & Quantity & $\begin{array}{l}\text { Percentage } \\
(\%)\end{array}$ & Quantity & $\begin{array}{l}\text { Percentage } \\
(\%)\end{array}$ \\
\hline Implementation of single control testing & 0 & 0 & 0 & 0 & 0 & 0 \\
\hline Implementation of single analytical procedure & 36 & 19,5 & 0 & 0 & 0 & 0 \\
\hline Implementation of single detailed testing & 51 & 27,4 & 22 & 11,8 & 23 & 12,4 \\
\hline $\begin{array}{l}\text { Combination of control testing and analytical pro- } \\
\text { cedure }\end{array}$ & 64 & 34,4 & 43 & 23,1 & 12 & 6,5 \\
\hline Combination of control testing and detailed testing & 20 & 10,8 & 45 & 24,4 & 25 & 13,4 \\
\hline $\begin{array}{l}\text { Combination of analytical procedure and detailed } \\
\text { testing }\end{array}$ & 15 & 8,1 & 76 & 40,9 & 43 & 23,1 \\
\hline $\begin{array}{l}\text { Combination of control testing, analytical proce- } \\
\text { dure and detailed testing }\end{array}$ & 0 & 0 & 0 & 0 & 83 & 44,6 \\
\hline
\end{tabular}

\section{Factors influencing audit quality of financial statements}

In Table 7, the items have mean values ranging from 3.48 to 4.27 . Besides, mean and mode values of all items are equal to 4, excepting item MT2 by 3 . Through descriptive statistics, we realize that most auditors agree that all factors affect the audit quality of financial statements in insurance enterprises. Skewness and Kurtosis coefficients are in $[-1 ; 1]$ so that all items have standard distribution.

Table 7

Descriptive statistics of variables

\begin{tabular}{|c|c|c|c|c|c|c|c|}
\hline Items & Mean & Mode & Std. Deviation & Skewness & Kurtosis & Minimum & Maximum \\
\hline LE1 & 3.88 & 4 & 0.74 & -0.131 & -0.468 & 2 & 5 \\
\hline LE2 & 3.84 & 4 & 0.702 & -0.428 & 0.358 & 2 & 5 \\
\hline LE3 & 3.87 & 4 & 0.724 & -0.232 & -0.16 & 2 & 5 \\
\hline PF4 & 4.04 & 4 & 0.554 & 0.019 & 0.301 & 3 & 5 \\
\hline PF5 & 3.97 & 4 & 0.5292 & -0.036 & 0.621 & 3 & 5 \\
\hline PF6 & 3.48 & 4 & 0.667 & -0.362 & -0.244 & 2 & 5 \\
\hline AA7 & 4.15 & 4 & 0.637 & -0.132 & -0.572 & 3 & 5 \\
\hline AA8 & 4.04 & 4 & 0.656 & -0.044 & -0.655 & 3 & 5 \\
\hline AA9 & 4.24 & 4 & 0.631 & -0.233 & -0.621 & 3 & 5 \\
\hline AQ10 & 4.26 & 4 & 0.622 & -0.241 & -0.607 & 3 & 5 \\
\hline AQ11 & 4.27 & 4 & 0.618 & -0.244 & -0.603 & 3 & 5 \\
\hline AQ12 & 4.18 & 4 & 0.646 & -0.185 & -0.651 & 3 & 5 \\
\hline AM13 & 4.02 & 4 & 0.611 & -0.008 & -0.279 & 3 & 5 \\
\hline AM14 & 4.17 & 4 & 0.529 & 0.156 & 0.18 & 3 & 5 \\
\hline AM15 & 4.18 & 4 & 0.526 & 0.178 & 0.15 & 3 & 5 \\
\hline AM16 & 4.08 & 4 & 0.578 & -0.001 & -0.016 & 3 & 5 \\
\hline CI17 & 4.15 & 4 & 0.724 & -0.228 & -1.065 & 3 & 5 \\
\hline CI18 & 4.06 & 4 & 0.683 & -0.075 & -0.84 & 3 & 5 \\
\hline CI19 & 3.95 & 4 & 0.676 & -0.154 & -0.213 & 2 & 5 \\
\hline CI20 & 4.02 & 4 & 0.606 & -0.009 & -0.238 & 3 & 5 \\
\hline CI21 & 3.92 & 4 & 0.689 & -0.095 & -0.378 & 2 & 5 \\
\hline FS1 & 4.18 & 4 & 0.519 & 0.218 & 0.169 & 3 & 5 \\
\hline FS2 & 4.12 & 4 & 0.51 & 0.197 & -0.591 & 3 & 5 \\
\hline FS3 & 4.19 & 4 & 0.545 & 0.091 & -0.066 & 3 & 5 \\
\hline FS4 & 3.97 & 4 & 0.628 & 0.019 & 0.43 & 3 & 5 \\
\hline
\end{tabular}

To evaluate the reliability of items, we test the Cronbach's Alpha and Corrected Item-Total Correlation coefficients. The results in Table 8 show that Cronbach's Alpha coefficients of all items in independent variables are greater than 0.6. Excepting item VT6, the remaining 20 items have Corrected Item-Total Correlation coefficient greater than 0.3. Therefore, variable VT6 is deleted from the model. Moreover, the reliability testing for dependent variable shows that the Cronbach Alpha coefficient is greater than 0.6 and Corrected Item-Total Correlation coefficient is greater than 0.3 (see Table 8). It is concluded that observational variables have the high reliability and enough condition for the exploratory factor analysis. 
Table 8

Reliability testing

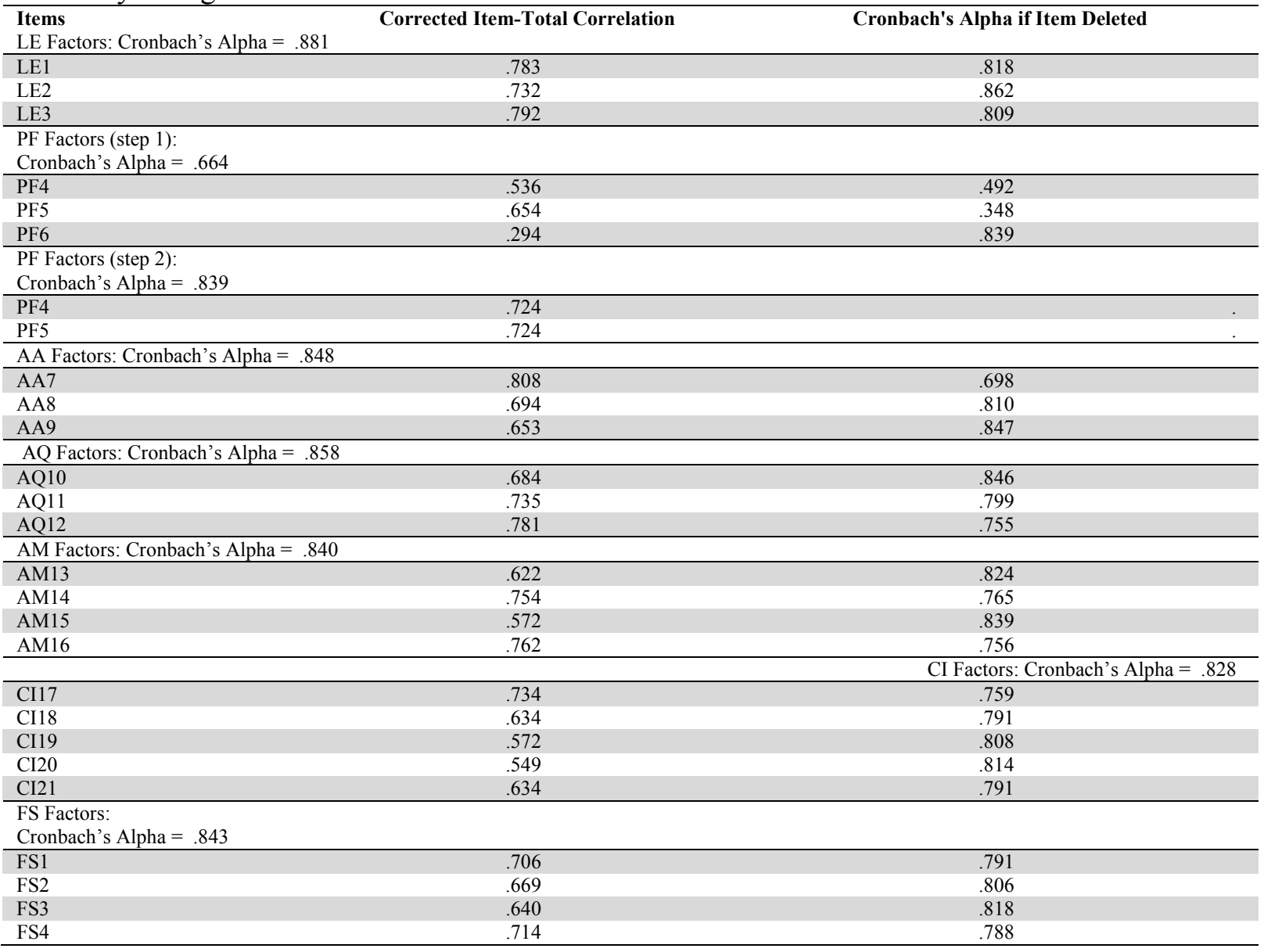

Table 9

Factor analysis to independent variables

\begin{tabular}{|c|c|c|c|c|c|c|}
\hline & \multicolumn{6}{|c|}{ Components } \\
\hline & 1 & 2 & 3 & 4 & 5 & 6 \\
\hline CI17 & 0.859 & & & & & \\
\hline CI18 & 0.77 & & & & & \\
\hline CI20 & 0.729 & & & & & \\
\hline CI21 & 0.704 & & & & & \\
\hline CI19 & 0.676 & & & & & \\
\hline AM14 & & 0.854 & & & & \\
\hline AM16 & & 0.843 & & & & \\
\hline AM13 & & 0.778 & & & & \\
\hline AM15 & & 0.724 & & & & \\
\hline LE1 & & & 0.895 & & & \\
\hline LE3 & & & 0.877 & & & \\
\hline LE2 & & & 0.849 & & & \\
\hline AA7 & & & & 0.91 & & \\
\hline AA8 & & & & 0.847 & & \\
\hline AA9 & & & & 0.81 & & \\
\hline AQ11 & & & & & 0.819 & \\
\hline AQ12 & & & & & 0.798 & \\
\hline AQ10 & & & & & 0.783 & \\
\hline PF5 & & & & & & 0.918 \\
\hline PF4 & & & & & & 0.907 \\
\hline KMO & 0.772 & & & & & \\
\hline Bartlett's Test of Spheriaty & Sig. $=0.000$ & & & & & \\
\hline Total variance extracted & $73.80 \%$ & & & & & \\
\hline Initial Eigenvalues & 1.126 & & & & & \\
\hline
\end{tabular}


Table 10

Factor analysis for dependent variable

\begin{tabular}{lcc}
\hline & & Component \\
& & 1 \\
\hline FS4 & & 0.849 \\
FS1 & & 0.844 \\
FS2 & & 0.819 \\
FS3 & 0.816 & 0.794 \\
\hline KMO & Sig. $=0.000$ & \\
Bartlett's Test of Spheriaty & $68.35 \%$ & \\
Total variance extracted & &
\end{tabular}

Table 9 and Table 10 show the results of exploratory factor analysis. For the independent variables, KMO coefficient is equal to $0.772(>0.5)$; the significance level of the Bartlett test is by 0.000 (Sig.< $0.05)$; The explanation variance is of $73.797 \%$ (> 50\%), Eigenvalues are greater than 1, all 20 observations have load factors greater than 0.5 and observation variables form six factors. Dependent variable has the KMO coefficient by 0.816 , Sig of Bartlett test by 0.000 , the explanation variance of $68.352 \%$ $(>50 \%)$, load factors greater than 0.5 , and observation variables form a factor. The results of Table 11 show the correlation coefficient between the independent variables and dependent variable with the lowest level by 0.273 and the highest level by 0.729 and sig value less than 0.05 . Thus, the dependent variable is strongly correlated with independent variables. On the other hand, in Table 12, the VIF variance coefficients of independent variables are less than 2 . Thus, there is no multi-collinearity between independent variables.

Table 11

Correlation between the dependent variable and independent variables

\begin{tabular}{|c|c|c|c|c|c|c|c|c|}
\hline & & FS & $\mathrm{LE}$ & $\mathrm{PF}$ & AA & AQ & $\mathrm{AM}$ & CI \\
\hline & Pearson Correlation & 1 & $.422^{* *}$ & $.273^{* *}$ & $.543^{* *}$ & $.729^{* *}$ & $.602^{* *}$ & $.477^{* *}$ \\
\hline \multirow[t]{3}{*}{ FS } & Sig. (2-tailed) & & .000 & .000 & .000 & .000 & .000 & .000 \\
\hline & $\mathrm{N}$ & 186 & 186 & 186 & 186 & 186 & 186 & 186 \\
\hline & Pearson Correlation & $.422^{* *}$ & 1 & .045 & .076 & $.373^{* *}$ & $.244^{* *}$ & $.234^{* *}$ \\
\hline \multirow[t]{3}{*}{ LE } & Sig. (2-tailed) & .000 & & .539 & .301 & .000 & .001 & .001 \\
\hline & $\mathrm{N}$ & 186 & 186 & 186 & 186 & 186 & 186 & 186 \\
\hline & Pearson Correlation & $.273^{* *}$ & .045 & 1 & $.184^{*}$ & .127 & .135 & $.029^{* *}$ \\
\hline \multirow[t]{3}{*}{$\mathrm{PF}$} & Sig. (2-tailed) & .000 & .539 & & .012 & .084 & .065 & .697 \\
\hline & $\mathrm{N}$ & 186 & 186 & 186 & 186 & 186 & 186 & 186 \\
\hline & Pearson Correlation & $.543^{* *}$ & .076 & $.184^{*}$ & 1 & $.334^{* *}$ & $.196^{* *}$ & $.178^{* *}$ \\
\hline \multirow[t]{3}{*}{ AA } & Sig. (2-tailed) & .000 & .301 & .012 & & .000 & .007 & .015 \\
\hline & $\mathrm{N}$ & 186 & 186 & 186 & 186 & 186 & 186 & 186 \\
\hline & Pearson Correlation & $.729^{* *}$ & $.373^{* *}$ & .127 & $.334^{* *}$ & 1 & $.415^{* *}$ & $.431^{* *}$ \\
\hline \multirow[t]{3}{*}{$\mathrm{AQ}$} & Sig. (2-tailed) & .000 & .000 & .084 & .000 & & .000 & .000 \\
\hline & $\mathrm{N}$ & 186 & 186 & 186 & 186 & 186 & 186 & 186 \\
\hline & Pearson Correlation & $.602^{* *}$ & $.244^{* *}$ & .135 & $.196^{* *}$ & $.415^{* *}$ & 1 & $.191^{* *}$ \\
\hline \multirow[t]{3}{*}{ AM } & Sig. (2-tailed) & .000 & .001 & .065 & .007 & .000 & & .009 \\
\hline & $\mathrm{N}$ & 186 & 186 & 186 & 186 & 186 & 186 & 186 \\
\hline & Pearson Correlation & $.477^{* *}$ & $.234^{* *}$ & .029 & $.178^{*}$ & $.431^{* *}$ & $.191^{* *}$ & $1^{* *}$ \\
\hline \multirow[t]{2}{*}{$\mathrm{CI}$} & Sig. (2-tailed) & .000 & .001 & .697 & .015 & .000 & .009 & \\
\hline & $\mathrm{N}$ & 186 & 186 & 186 & 186 & 186 & 186 & 186 \\
\hline
\end{tabular}

To examine the relationship between independent variables and dependent variables, we perform the regression model testing by using the Stepwise method. In particular, the sixth model is the best model with adjusted $R^{2}$ coefficient by 0.778 and Sig of $F$ test less than 0.05 (see Table 12). Therefore, the independent variables in the model explain $77.8 \%$ of the change about the audit quality of a financial statements in the insurance enterprises. 
Table 12

Results of regression model testing (model 6)

\begin{tabular}{lcccccc}
\hline & $\mathrm{B}$ & Std. Error & Beta & $\mathrm{t}$ & Sig. & VIF \\
\hline (Constant) & -.820 & .215 & & -3.816 & .000 & \\
AQ & .292 & .036 & .356 & 8.030 & .000 & 1.640 \\
AM & .307 & .038 & .311 & 8.083 & .000 & 1.237 \\
AA & .243 & .030 & .299 & 8.025 & .000 & 1.163 \\
CI & .152 & .034 & .174 & 4.502 & .000 & 1.241 \\
LE & .101 & .026 & .145 & 3.831 & .000 & 1.189 \\
PF & .108 & .032 & .119 & 3.362 & .001 & 1.049 \\
\hline R Square & .786 & & F=10.9.331 Sig (F) & .000 & \\
Adjusted R Square & & .778 & & Durbin-Watson & 1.875 &
\end{tabular}

It is found that six hypotheses including $\mathrm{H} 1, \mathrm{H} 2, \mathrm{H} 3, \mathrm{H} 4, \mathrm{H} 5, \mathrm{H} 6$ are accepted and the regression equation is as follows:

$\mathrm{FS}=-0.820+0.292 \mathrm{AQ}+0.307 \mathrm{AM}+0.243 \mathrm{AA}+0.152 \mathrm{CI}+0.101 \mathrm{LE}+0.108 \mathrm{PF}$

\section{Conclusion}

First, the study has indicated that both big four and non-big four firms were well aware of audit techniques and procedures and they applied these techniques and procedures in auditing financial statements to obtain appropriate audit evidences. Document testing technique has still been used most commonly. At the same time, according to the research results, the implementation of risk-based approach has created the necessary changes on the application level of audit techniques and procedures as well as differences between the two audit groups. There were different form of material testing, observation, interview, calculation and analysis techniques. Of which, interview and analysis techniques have maintained the most significantly difference between the two groups. Secondly, while control testing was not performed alone, the analysis procedure has been implemented alone at the assurance level by 1 and the detailed testing can be performed alone at all three assurance levels. It is possible to combine two procedures at the assurance level of 2 and 3. On the other hand, the combination of these three procedures is only at the level 3. Finally, the results have determined that all six factors impacting on audit quality of financial statements. As a result, audit method is ranked first, followed by quality of auditors, awareness of auditors and director board, the characteristics of insurance enterprises, the position of audit firms and the least important factor is legal environment. Therefore, in order to improve audit quality of the financial statements in insurance enterprises, solutions not only focus on completing the audit process of the financial statements by auditors, but also need to be linked with the audit firms, state functional agencies and insurance enterprises.

\section{References}

Vitalis, A. M. (2012). Business risk and audit risk: An integrated model with experimental boundary test (Doctoral dissertation, The University of Wisconsin-Madison).

Aldhizer III, G. R., Miller, J. R., \& Moraglio, J. F. (1995). Common attributes of quality audits. Journal of Accountancy, 179(1), 61-68.

Bell, T.B, Marrs, F.O., Solomon, I., Thomas, H. (1997). Auditing organizations through a strategic-systems lens: The KPMG Business Measurement Process. KPMG Peat Marwick LLP.

Boon, K., McKinnon, J., \& Ross, P. (2008). Audit service quality in compulsory audit tendering: Preparer perceptions and satisfaction. Accounting Research Journal, 21(2), 93-122.

Bui, T.T. (2014). Research factors influencing to audit quality of financial statements in enterprises on Vietnamese stock market. Doctoral Thesis. National Economics University.

Carcello, J. V., Hermanson, R. H., \& McGrath, N. T. (1992). Audit quality attributes: The perceptions of audit partners, preparers, and financial statement users. Auditing, 11(1), 1-15.

Cullinan, C. P., \& Sutton, S. G. (2002). Defrauding the public interest: a critical examination of reengineered audit processes and the likelihood of detecting fraud. Critical Perspectives on Accounting, 13(3), 297-310.

DeAngelo, L. E. (1981). Auditor independence, 'low balling', and disclosure regulation. Journal of accounting and Economics, 3(2), 113-127. 
DeFond, M., \& Zhang, J. (2014). A review of archival auditing research. Journal of Accounting and Economics, 58(2-3), 275-326.

Dinh, T.T.H. (2015). Application of audit methodologies in financial statement audit conducted by audit firm in Vietnam. Doctoral Thesis, Academy of finance.

Do, H., \& Trung, N.S. (2016). The factors affect the quality of financial statements audit in Vietnam businesses. Asian Social Science, 12(1), 172-186.

Duff, A. (2004). Dimentions of audit quality. The Institute of Chartered Accountants of Scotland.

Griffiths, P. (2005). Risk-based Auditing. Gower E-book.

Financial Reportig Council (FRC) (2008). The audit quality framework. Available at: http://www.frc.org.uk/Our -Work/ Publications/FRC -Board/The-Audit-Quality-Framework-\%281\%29.aspx.

Granberg, L., \& Hoglund, L. (2011). The auditor's way to acquire knowledge about a company's environment. Master Thesis, Kristianstad University.

Hair, J. F., Black, W. C., Babin, B. J., \& Anderson, R. E. (2009). Multivariate Data Analysis 7th Edition Pearson Prentice Hall.

Knechel, W. R. (2007). The business risk audit: Origins, obstacles and opportunities. Accounting, Organizations and Society, 32(4-5), 383-408.

Low, K.Y. (2004). The effects of industry specialization on audit risk assessments and audit-planning decisions. The Accounting Review, 79(1), 201-219.

Malaescu, I., \& Sutton, G.S. (2013). The Reliance of External Auditors on Internal Audit's Use of Continuous Audit. Doctoral Thesis. University of Central Florida.

Martar, S. (2012). The Impact of Legal Responsibility of External Auditors on Auditing Quality and Investment Level. Department of Economics of Finance, Brunel University.

Mentz, M. (2014). Audit evidence enables the auditor to express an opinion on the financial statements to address the risk that the auditor may express. Doctoral Thesis. University of South Africa.

Messier, S.A., Bernardi, R.A., \& Bernard, J.J. (2014). Review of the impact of client trustworthiness on the audit decision-making Process. Journal of Forensic \& Investigative Accounting, 6, 222-247.

Moroney, R (2007). Does industry expertise improve the efficiency of audit judgment?. Auditing: A Journal of Practice \& Theory, 26(2), 69-94.

Munro, L., \& Stewart, J. (2009). External auditors' reliance on internal audit: the impact of sourcing arrangements and consulting activities. Discussion papers accounting, University Griffith .

Palmrose, Z.V. (1988). An Analysis of Auditor Litigation and Audit Service Quality. The Accounting Review, 63(1), 55-73.

Phan, V.D. (2015). The factors affecting Audit quality of Audit Firms in Vietnam oriented to strengthen competitive capability in international integration conditions. Doctoral Thesis. University of Economics Ho Chi Minh City.

Prinsloo, J (2008). The development and evaluation of risk-based audit approaches. Magister in accounting. University of the Free State.

Richard, C.H., \& Jason, L.D. (2006). Employee Theft and Staff Dishonesty. The handbook of security, 9, 203-228.

Tabachnick, B. G., \& Fidell, L. S. (2007). Using multivariate statistics. (5th ed.). Boston, MA: Allyn \& Bacon/Pearson Education.

Tuukka, J. (2012). Factors Influencing Auditors' Information Usage: Experience, Risk, Task Structure and Information Reliability. ACTA Wasaensia No 272. Universitas Wasaensis.

Salterio, S. E., \& Weirich, T.R. (2002). A primer on the strategic-systems approach to auditing. University of Waterloo working paper.

Sarwoko, I., \& Sukrisno, A. (2014). An empirical analysis of auditor's industry specialization, auditor's independence and audit procedures on audit quality: Evidence from Indonesia. Procedia-Social and Behavioral Sciences, 66, 271-181.

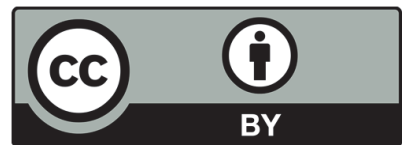

(C) 2019 by the authors; licensee Growing Science, Canada. This is an open access article distributed under the terms and conditions of the Creative Commons Attribution (CC-BY) license (http://creativecommons.org/licenses/by/4.0/). 